\title{
Cadets' Effectivity and Perception on Moodle Online Learning in Economy Mathematics Course
}

\author{
Ningrum Astriawati ${ }^{1, *}$, Himawan Aditya Pratama ${ }^{2}$ \\ ${ }^{1}$ Ship Machinery Study Program, Yogyakarta Maritime College \\ ${ }^{2}$ Transportation Study Program, Yogyakarta Maritime College \\ *Corresponding author. Email: astriamath@gmail.com
}

\begin{abstract}
This research aims to describe the effectiveness and see the tendency of cadets' perceptions of moodle-based online learning during the Covid-19 pandemic in the Economy Mathematics Course. The research population was all cadets who took the Economy Mathematics Online Course at the Yogyakarta Maritime College. The sample of the research were cadets for the Transportation Study Program and Marine Transportation Management Study Program which were selected using a simple random sampling technique by considering population homogeneity. This research is descriptive research with data collection techniques using an online questionnaire. The results showed that cadets rated moodlebased online learning in the Economy Mathematics Course as highly effective (10.75\%), most of them rated it as effective (50.54\%), and rated it as normal (24.73\%). Although there are also cadets who consider online learning ineffective $(9.68 \%)$ and poorly effective $(4.30 \%)$. Cadets have a positive perception of moodle-based learning in Economy Mathematics Course, both in terms of material, interaction, and learning environment.
\end{abstract}

Keywords: Economy Mathematics Course, Moodle, Effectiveness, Cadets' Perceptions.

\section{INTRODUCTION}

The mother of the science of all disciplines is mathematics, this is because mathematics is the basis for the development of other sciences and is always developing both in the aspects and dimensions of the transition of science and mathematics education in today's informational society[1]. This is why mathematics is one of the compulsory subjects for formal schools for curricula in various countries from elementary to college-level [2]. At the College level, especially at the Yogyakarta Maritime College, there is a Economy Mathematics Course. This course provides knowledge of the basic concepts of mathematics and the skills to apply mathematical thinking in economic decisions. Learning contains the delivery of basic mathematical formulas that are relevant and practiced in working on problems that have to do with economics $[3,4]$.

There are still many students who consider mathematics a difficult subject to be one of the problems faced by educators today[5]. Mathematics is considered a difficult subject because of the characteristics of mathematics which are abstract, logical, systematic, and full of puzzling symbols and formulas[6, 7]. The difficulties in mathematics require the creativity of mathematics lecturers to develop their learning, both in terms of the media or the methods used. Interactive media can reduce student difficulties in the lecture process and can increase student understanding of a concept in mathematics[8]. Mathematics learning which is already considered difficult by most students is faced with new potential obstacles, namely a change in the pattern of implementing learning from face-to-face to online learning this is due to the Covid-19 pandemic that has hit all countries in the world, including Indonesia.

Online lectures are the policy of the Indonesian government to control the spread of covid-19[9] Online learning is a learning process that does not require faceto-face interaction between lecturers and students but utilizes internet networks and is assisted by various applications that support the learning process[10]. Online learning is one form of internet use that can increase the role of students in learning. The online media that has been implemented at the Yogyakarta Maritime College is Edmodo[11]. Edmodo is one of the courageous media that can improve the learning outcomes of cadets, but Edmodo has a drawback, namely Edmodo structure is informal education[12]. It takes other bold media to be implemented in cadets, one of which is moodle. MOODLE (short for Modular Object-Oriented Dynamic Learning Environment) is a software feature package 
created for internet-based learning activities and websites that use the principles of social constructionist pedagogy[13]. Moodle can improve student learning activity[14]. Moodle is being developed at the Yogyakarta Maritime College, this is because Moodle is a complete package for online learning. In implementing moodle-based online learning, it is necessary to evaluate in order to obtain clear corrective steps based on data. Therefore it is necessary to conduct research to see the effectiveness and perceptions of cadets towards online learning, especially for subjects that are considered difficult by cadets, namely Economy Mathematics Course. The purpose of this study was to see the effectiveness and perceptions of cadets towards moodlebased online learning in Economy Mathematics Course. By knowing the tendency of cadets' perceptions, various actions can be taken to improve the quality of learning.

\section{METHOD}

This research is quantitative descriptive research to describe the effectiveness and see the tendency of cadets' perceptions of moodle-based online learning during the Covid-19 pandemic in the Economy Mathematics Course. Descriptive research is a quantitative research method that attempts to collect quantifiable information for statistical analysis of the population sample[15]. The technique of collecting data uses an online questionnaire with the help of google form. The research population was all cadets who took Economy Mathematics Course at the Yogyakarta Maritime College, totaling 109 cadets, only 93 cadets who gave responses. Based on the Slovin formula with a tolerance of $5 \%$ the number of samples of 86 people has been fulfilled[16]. Samples were taken using a simple random sampling technique with the assumption that the conditions and readiness of Yogyakarta Maritime College cadets to attend online courses are homogeneous because all cadets are conducting full online courses for the first time. In this research, perceptions will be specifically discussed regarding cadets' perceptions of Economy Mathematics Course material, learning environment, and interaction patterns during online learning.

\section{RESULT AND DISCUSSION}

Moodle is designed to support online cadets' activities. To be able to access Moodle, cadets must have a username and password to be registered. After that, cadets can log into Moodle by accessing the link http://vclass.stimaryo.ac.id:8072/vclass/.

After successfully logging into Moodle, the cadets can enter the class and the admin must activate the cadets' accounts, then the cadets can access and attend online learning. The following is the initial appearance as a lecturer to create a course on Moodle:

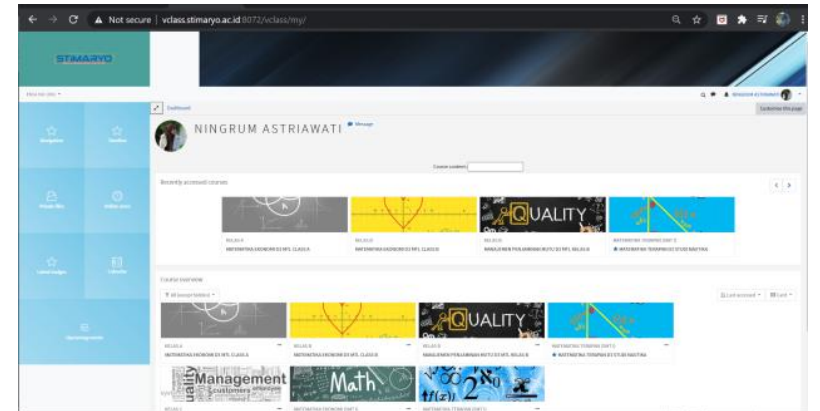

Figure 1. Initial Appearance Of Creating A Courses In Moodle

In the courses that have been designed, several learning activities will support cadets doing online activities. In this study, the Economy Mathematics Course has several activities of cadets about moodle. Where each activity has a different function in the implementation of lectures. Activities available include Assignment, Attendance, BigBlueButtonBN, Chat, Choice, Database, External tool, Feedback, Forum, Glossary, Group choice, Lesson, Questionnaire, Quiz, Registration date, SCORM package, Survey, Via, Wiki, Workshop, Zoom meeting, for RESOURCES equipped with Book, File, Folder, IMS content package, Label, Page, and URL. Activities in moodle-based lectures are as shown in Figure 2.

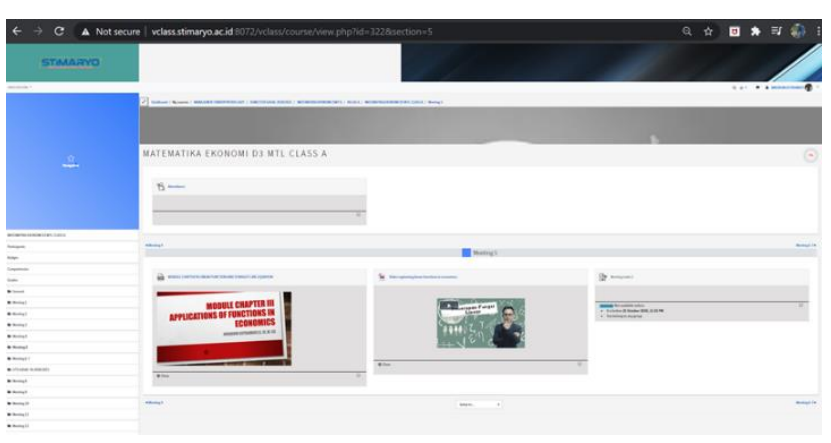

Figure 2. Lecture Activities in Economy Mathematics Course Using Moodle

\subsection{Assessment of the Effectiveness of Online Learning Based on Moodle in Economy Mathematics Course}

Online learning is the main key to implementing learning during the Covid 19 pandemic and the New Normal era, this requires the readiness of students and students to do Study From Home. Several studies have measured the effectiveness of online learning using Moodle, including Zainul's research which states that Moodle e-learning products can be effectively used widely in College institutions in Indonesia[17]. Another study, Sánchez, stated that the use of moodle is also directly influenced by the perceived ease of use and attitudes that can increase the effectiveness and motivation of students[18]. 
The use of moodle in the Economy Mathematics Course in the Marine Transportation Management Study Program and Transportation Study Program, Yogyakarta Maritime Collage by using Moodle is felt to be effective. This can be seen from the assessment of the questionnaire that was distributed online to cadets. The results of the cadets' assessment of moodle-based online learning in the Economy Mathematics Course were very effective at
$10.75 \%$, most of them rated it as effective with a percentage of $50.54 \%$, and rated it as normal at $24.73 \%$. Although there were also cadets who considered online learning ineffective with a percentage of $9.68 \%$ and very ineffective at $4.30 \%$. This can be seen in Figure 3 below.

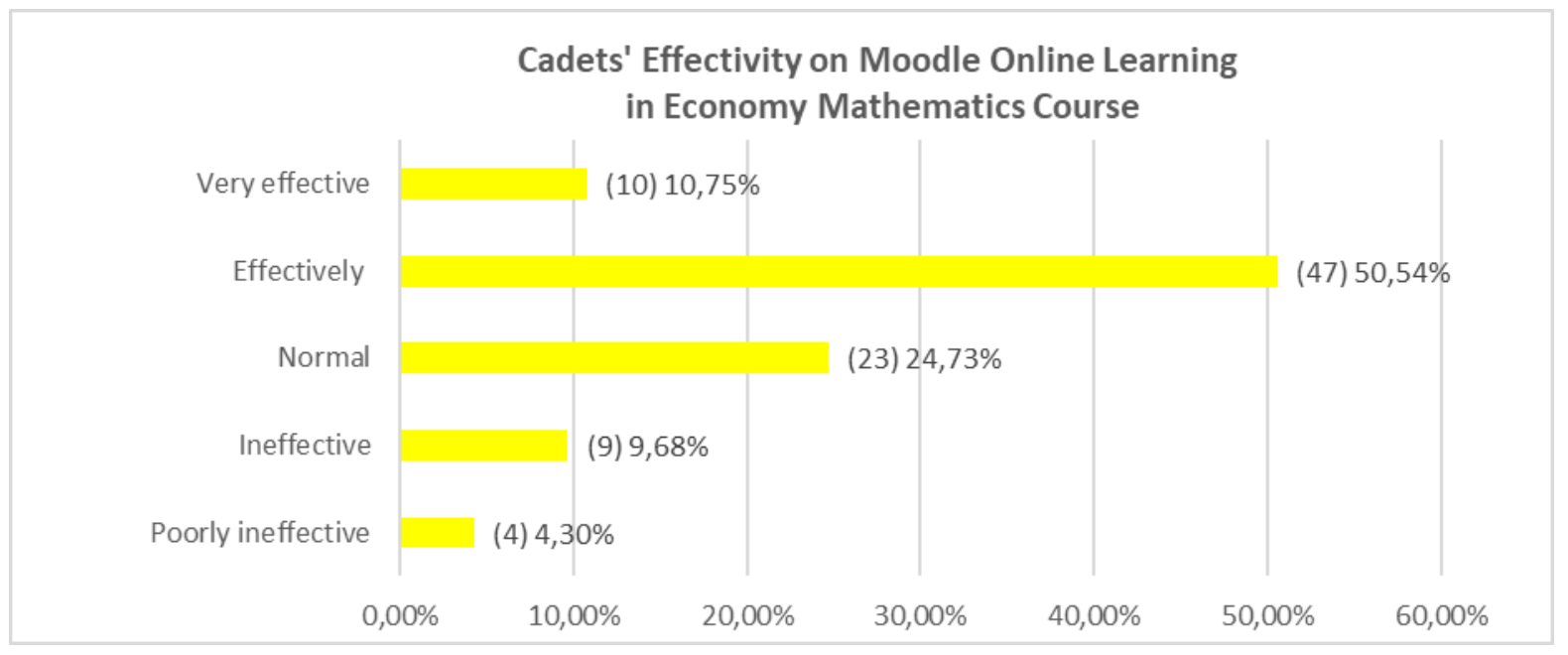

Figure 3. Cadets' Effectivity on Moodle Online Learning in Economy Mathematics Courses

Assessment of the effectiveness of moodle-based online learning in the Economy Mathematics Course is effective and very effective at $61.29 \%$, this has an impact on cadets having a high enthusiasm for learning and doing assignments seen from the activity of cadets who mostly collect assignments in Moodle. The survey results also showed an increase in the cadets' learning motivation by $76 \%$ while using Moodle. The results of Simanullang's research show that there is a significant influence on the use of moodle-based learning media on student activities[14]. This is reinforced by the results of Chootongchai's research which shows the use of LMS moodle can improve students' thinking and innovation skills[19]. So that the use of moodle in College needs to be improved.

\subsection{Cadets' Perceptions of Moodle-Based Online Learning in Economy Mathematics Course}

Perception is an experience about objects, events, or relationships obtained by formulating data and interpreting messages. Perception can also be defined as the process by which people interpret and organize stimulus patterns in a place[20]. It can be concluded that perception is the meaning given by people to the stimulus it receives. The stimulus can be in the form of objects or events that are accepted by the human senses or experienced by feelings[21]. Perception can be classified into two, namely positive perception and negative perception. Positive perception is an individual's assessment of an object or information with a positive view or by what is expected from the object being perceived or from existing rules. Meanwhile, negative perceptions are individual perceptions of certain objects or information with a negative view, contrary to what is expected from the object being perceived or from existing rules[22]. Mulyana's research results show that there is a positive relationship between perceptions of learning and learning outcomes[23] . For this reason, it is necessary to know how cadets' perceptions of moodlebased online learning in Economy Mathematics Course will then be used as a reference in the implementation of subsequent online learning.

Three aspects are used as analysis related to perceptions in online learning, namely: aspects of teaching materials, aspects of learning interactions, and aspects of the learning environment. The perception assessment uses an online questionnaire with a linear scale from 1-5. Point 1 for an assessment of very negative perceptions, point 2 for an assessment of negative perceptions, point 3 for an assessment of normal/normal perceptions, point 4 for an assessment of positive perceptions, and point 5 for an assessment of very positive perceptions. The following are the results of the assessment of cadets' perceptions of moodle-based online learning in the Economy Mathematics Course which is assessed in 3 aspects: 


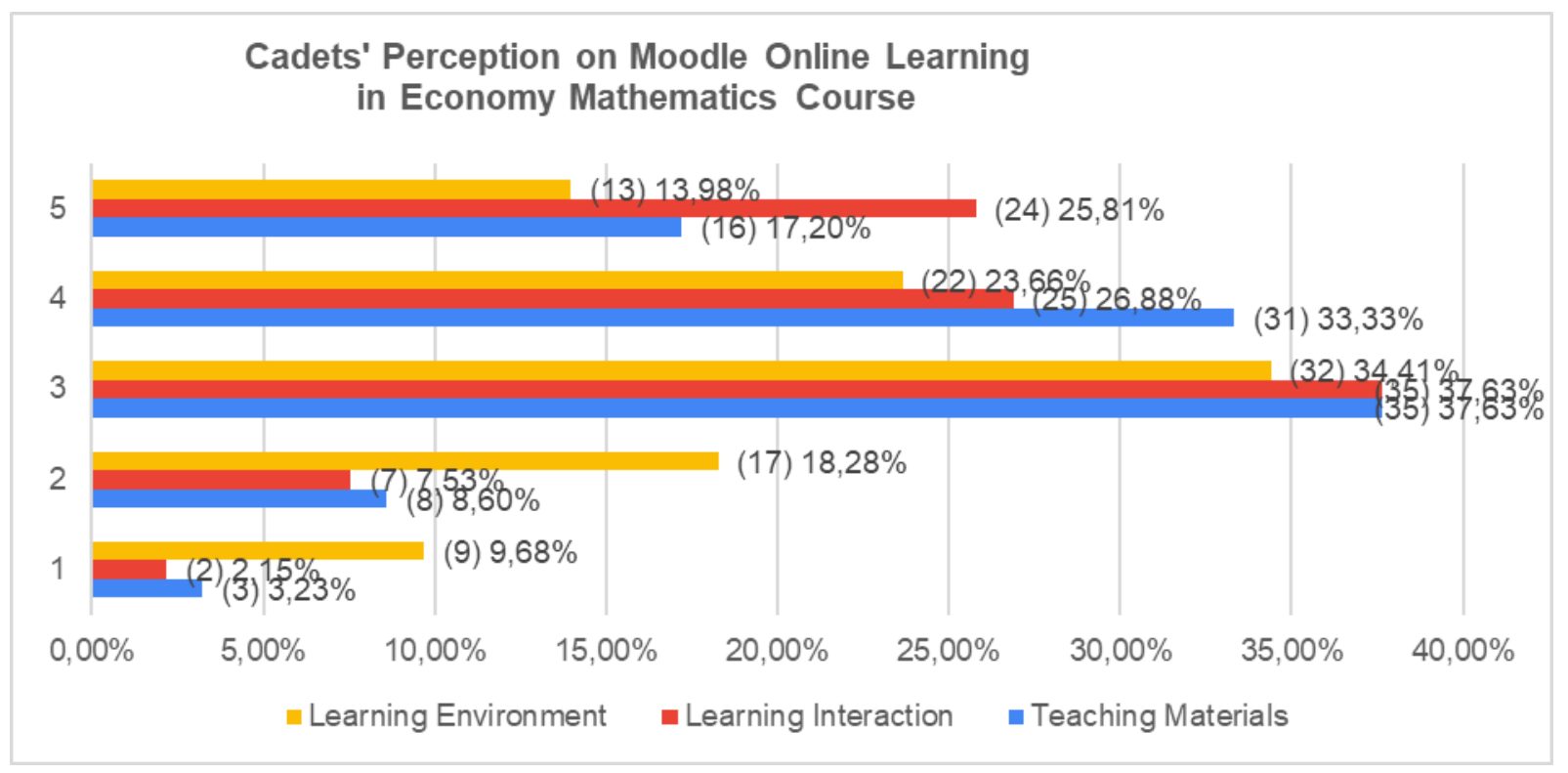

Figure 4. Cadets' Perception of Moodle Online Learning in Economy Mathematics Course

Teaching material/teaching modules are modules that must be informed to students, which contain concepts, theories, or laws that lead to the achievement of educational goals[24]. During online learning, the presentation of the teaching module certainly cannot be presented directly by lecturing to students, so that lecturers need to prepare teaching materials which after that must be distributed to cadets via the internet. Teaching materials are all materials (both data, equipment, or reading) that are arranged systematically, which shows the full form of competencies that students want to understand and use in the educational process with the aim of planning and studying education implementation. The perceptions of cadets regarding the quality of teaching modules in the form of materials, PowerPoint slides, graphic news, photos, animations, and videos by lecturers in the Economy Mathematics Course are very positive $(17.20 \%)$, assess positively $(33.33 \%)$, and assess mediocrity (37.63\%), although there were also cadets who considered the teaching materials delivered by the lecturers to Moodle $(8.60 \%)$ and very negative $(3.23 \%)$. The answers to the questionnaire show that in general, the lecturers have presented good teaching materials during online learning. Good teaching materials can improve cadets' learning outcomes[25].

Learning interactions include interactions between cadets and lecturers and interactions between cadets. Good learning interactions support the achievement of good learning outcomes. Ni's research states that the quality and quantity of online learning interactions can be improved to support the achievement of good learning outcomes[26]. Perceptions of cadets regarding learning interactions between cadets and lecturers and interactions between cadets in the moodle-based Economy
Mathematics Course course get very positive perceptions (25.81\%), assess positively (26.88\%), and assess mediocrity $(37.63 \%)$, although there are also cadets who perceive learning interactions in moodle-based online classes as negative $(7.53 \%)$ and very negative $(2.15 \%)$. The answers to the questionnaire indicate that in general, the lecturers have had good learning interactions during the online Moodle-based lectures.

A good learning environment is an environment that can create calm and can motivate to learn better[27]. Perceptions of cadets regarding the learning environment in the Economy Mathematics Course get very positive perceptions $(13.98 \%)$, assess positively $(23.66 \%)$, and assess mediocrity (34.41\%) although there are also cadets who perceive the learning environment in moodle-based online classes negatively $(18.28 \%)$ and very negative $(9.68 \%)$. The answers to the questionnaire show that the learning environment gets good perceptions during moodle-based online lectures. Cadets feel that online learning is more flexible because it can be done anywhere and without the need for preparations such as bathing and dressing up for campus.

\section{CONCLUSION}

Moodle-based online learning during the covid-19 pandemic in Economy Mathematics Course gave positive results. The results showed that cadets rated moodlebased online learning in the Economy Mathematics Course as very effective at $10.75 \%$, most of them rated it as effective with a percentage of $50.54 \%$, and rated it as normal at $24.73 \%$. Although there were also students who considered online learning ineffective with a percentage of $9.68 \%$ and very ineffective at $4.30 \%$. The results of the study also showed that cadets had a positive 
perception of moodle-based online learning in Mathematics in terms of material, interaction, and learning environment.

\section{AUTHORS' CONTRIBUTIONS}

N.A.W conceived the original idea. This was also discussed with H.A.P, all authors discussed and agreed with the main focus and ideas of this paper. The main text of the paper was written by N.A.W and then translated by H.A.P also edit the manuscript. N.A.W distributed questionnaires then analyzed the results of the questionnaire assisted by the H.A.P

\section{ACKNOWLEDGMENTS}

This research was funded by the Institute for Research and Community Service of the Yogyakarta Maritime College in the 2020 funding year. We are grateful to all those who have provided assistance and support for this research.

\section{REFERENCES}

[1] O. Skovsmose, P. Valero, and O. R. Christensen, University science and mathematics education in transition. 2009.

[2] J.-H. Woo, H.-C. Lew, K.-S. P. Park, D.-Y. Seo, and I. G. for the P. of M. Education., "Proceedings of the Conference of the International Group for the Psychology of Mathematics Education (31st, Seoul, Korea, July 8-13, 2007). Volume 2," Int. Gr. Psychol. Math. Educ., 2007.

[3] Tim Akademik, "Rencana pembelajaran semester," Sekol. Tinggi Marit. Yogyakarta, vol. 1, no. September, pp. 1-6, 2019.

[4] "Fundamental methods of mathematical economics," J. Macroecon., vol. 6, no. 2, p. 239, Mar. 1984.

[5] M. Păun, "Teaching mathematics," in APLIMAT 2015 - 14th Conference on Applied Mathematics, Proceedings, 2015.

[6] D. A. Krisma and H. Retnawati, "The final semester test of mathematics subject in vocational high school, how difficult is it?," $J$. Phys. Conf. Ser., vol. 1581, no. 1, 2020.

[7] P. Grootenboer and R. Zevenbergen, "Identity as a lens to understand learning mathematics: Developing a model," Proc. 31st Annu. Conf. Math. Educ. Res. Gr. Australas., pp. 243-254, 2008.

[8] N. Astriawati, W. Wibowo, and H. Widyanto, "Designing Android-Based Augmented Reality Application on Three Dimension Space Geometry," in Journal of Physics: Conference
Series, 2020.

[9] Surat Edaran Mendikbud Nomor: 36962/MPK.A/HK/2020, "Pembelajaran secara Daring dan Bekerja dari Rumah dalam Rangka Pencegahan Penyebaran Corona Virus Disease (COVID-19)."

[10] O. Learning, "Research on the Effectiveness of Online Learning," Cost Effic. Online Learn. ASHE High. Educ. Rep., 2011.

[11] W. Wibowo and N. Astriawati, "The effectiveness of using Edmodo based e-learning in the applied mechanics course," in Journal of Physics: Conference Series, 2020.

[12] T. Trust, "Motivation, Empowerment, and Innovation: Teachers' Beliefs About How Participating in the Edmodo Math Subject Community Shapes Teaching and Learning," $J$. Res. Technol. Educ., vol. 49, no. 1-2, pp. 16-30, Apr. 2017.

[13] Moodle, "Moodle - Open-source learning platform | Moodle.org," Moodle.org, 2018. .

[14] N. H. S. Simanullang and J. Rajagukguk, "Learning Management System (LMS) Based on Moodle to Improve Students Learning Activity," J. Phys. Conf. Ser., vol. 1462, no. 1, 2020.

[15] K. Charry et al., "Descriptive Analysis," in Marketing Research with IBM® SPSS Statistics, Routledge, 2020, pp. 31-47.

[16] A. Hidayat, "Cara Perhitungan Rumus Slovin Besar Sampel Minimal," Statistikian, 2017. .

[17] R. Zainul et al., "Development of e-Learning Courses for Subjects about 'Learn and Learning' with Moodle-based for Prospective Teacher in Indonesia," J. Phys. Conf. Ser., vol. 1594, p. 012023, Jul. 2020.

[18] R. A. Sánchez and A. D. Hueros, "Motivational factors that influence the acceptance of Moodle using TAM," Comput. Human Behav., 2010.

[19] S. Chootongchai and N. Songkram, "Design and development of SECI and moodle online learning systems to enhance thinking and innovation skills for higher education learners," Int. J. Emerg. Technol. Learn., 2018.

[20] M. F. Saifuddin, "E-Learning dalam Persepsi Mahasiswa," J. VARIDIKA, 2018.

[21] C. N.H. Zhafira, Y. Ertika, "Daring Sebagai Sarana Pembelajaran Selama Masa Karantina Covid-19," J. Bisnis dan Kaji. Strateg. Manaj., vol. 4, no. 1, pp. 37-45, 2020.

[22] H. A. Maulana and M. Hamidi, "Persepsi Mahasiswa terhadap Pembelajaran Daring pada Mata Kuliah Praktik di Pendidikan Vokasi," Equilib. J. Pendidik., vol. 8, no. 2, pp. 224-231, 
Jun. 2020.

[23] A. Mulyana, S. Hidayat, and S. Sholih, "Hubungan Antara Persepsi, Minat, dan Sikap Siswa dengan Hasil Belajar Siswa dalam Pembelajaran PKn," J. Pendidik. dan Kebud., 2013.

[24] H. Fry, A Handbook for Teaching and Learning in Higher Education. 2014.

[25] N. Astriawati, W. Wibowo, and W. Pratama, "Developing Mathematics Learning Materials Based on CO-PROL to Improve Cadets' Learning Outcomes," J. Phys. Conf. Ser., vol. 1315, p. 012059, Oct. 2019.

[26] A. Y. Ni, "Comparing the Effectiveness of Classroom and Online Learning: Teaching Research Methods," J. Public Aff. Educ., 2013.

[27] S. Sardiyanah, "BELAJAR DAN FAKTOR YANG MEMPENGARUHINYA," J. Al-Qalam J. Kaji. Islam Pendidik., 2020. 